\title{
Penyuluhan dan Deteksi Dini Anemia menuju Generasi Berkualitas pada Mahasiswa Kebidanan
}

\author{
Marlynda Happy Nurmalita Sari ${ }^{1 *}$, Dina Dewi Anggraini ${ }^{2}$ \\ ${ }^{1,2}$ Poltekkes Kemenkes Semarang \\ *Email: marlyndasari89@gmail.com
}

\begin{abstract}
Background: The prevalence of anemia in adolescent girls in Indonesia is still high at 57.1\%. As a result of anemia is adolescent learning achievement can decrease, work productivity decreases and body immunity decreases so that the body is easily infected. Long-term effects of anemia in adolescent girls can occur complications of pregnancy and even the risk of maternal and perinatal death. Purpose of this studi is provide counseling and early detection of anemia to Midwifery students as an effort to make them aware in preventing and overcoming anemia. Methods: The target of this activity is 132 students of the Blora Midwifery Diploma Program. This activity is carried out by providing information or knowledge in the form of counseling to students about anemia and followed by history and physical examination. Only students who showed signs and symptoms of anemia who were tested for HB levels were 30 students. Results: Early detection of 30 students there were $53.3 \%$ who were not anemic and $46.7 \%$ were anemic. Most of the students' menstruation period is 6-7 days which is $73.3 \%$. While the results of counseling some students already understand about anemia. Conclusion: Of the 132 students only 30 showed signs and symptoms of anemia. Hb examination results are almost the same between respondents who are anemic and not anemic. It is hoped that the results of community service activities can be used as an illustration of the incidence of anemia in Midwifery students so that efforts can be made to prevent and manage anemia. Provide motivation and awareness to students to consume nutritious and iron-containing foods or to consume extra blood tablets.
\end{abstract}

Keywords: Anemia, Anemia counseling, Early detection of anemia, Midwife Hb levels

\section{PENDAHULUAN}

Sebagian besar remaja tidak tahu atau tidak menyadari akibat dari anemia. Bahkan mereka menganggap anemia sebagai masalah yang tidak penting dan tidak perlu mendapatkan perhatian khusus (Yusuf, 2011). Dari semua remaja di negara berkembang prevalensi anemia remaja putri yaitu 53,7\% (WHO, 2010). Lebih dari $30 \%$ penduduk di dunia yang tinggal di daerah tropik sebagian besar mengalami anemia dan. Berdasarkan World Health Organization (WHO) (2007) di Indonesia prevalensi anemia pada wanita usia produktif yang tidak hamil adalah 33,1\%. Pendapat lain Bakta I.M. (2009) mengatakan di Indonesia remaja putri angka prevalensinya yaitu $57,1 \%$. 
Data Survei Kesehatan Rumah Tangga (SKRT) (2012) menyatakan bahwa yang mengalami anemia defisiensi prevalensinya yaitu 39,5\% umur 19-45 tahun, 57,1\% umur 10-18 tahun (remaja putri), 45,1\% ibu nifas, 50,5\% ibu hamil dan 40,5\% balita (Kemenkes RI, 2013). Dapat dilihat dari data tersebut bahwa remaja putri yang mempunyai resiko paling besar. Hal ini diperkuat oleh pendapat dari Permaesih dan Permaesih D. dan Herman S. (2005) bahwa 25,5\% prevalensi anemia pada remaja untuk umur 10-19 didominasi remaja putri 30\% dibandingkan remaja putra yang hanya $21 \%$. Anemia merupakan suatu keadaan apabila kadar $\mathrm{Hb}$ kurang dari normal yaitu $\mathrm{Hb}<12 \mathrm{gr} / \mathrm{dl}$. Apabila remaja putri kadar $\mathrm{Hb} \geq 12 \mathrm{gr} / \mathrm{dl}$ maka dikatakan normal atau tidak anemia, sedangkan apabila remaja putri kadar $\mathrm{Hb}$ $<12$ gr/dl maka dikatakan anemia (Proverawati, 2011).

Faktor penyebab remaja putri menderita anemia antara lain karena saat usia remaja mengalami pertumbuhan dimana hal ini membutuhkan asupan zat gizi lebih tinggi terutama zat besi, tetapi remaja putri tidak memperhatikan jumlah makanan, atau penyerapan diet yang buruk, menstruasi yang berlebihan, adanya penyakit infeksi yang kronis, perdarahan yang mendadak seperti kecelakaan (Merryana, 2012). Apabila remaja putri kekurangan zat besi (menderita anemia) akan mengakibatkan remaja putri dalam kondisi tubuh merasa lemah, letih dan lesu, muka tampak pucat, kepala sering pusing dan konsenterasi menurun. Adapun hasil analisis faktor penyebabnya adalah pendidikan kedua orang tua, pengetahuan dari remaja putri itu sendiri tentang anemia, faktor ekonomi keluarga, konsumsi tablet $\mathrm{Fe}$, konsumsi Vit $\mathrm{C}$ dan lamanya remaja putri menstruasi (Burner, 2012).

Adapun akibat jangka panjang pada remaja putri yang mengalami anemia bahwa jika dia nanti hamil, maka remaja putri tidak akan dapat memenuhi zat-zat gizi untuk tubuhnya dan juga janin yang dikandungannya. Apabila remaja putri tersebut hamil dengan anemia dapat beresiko untuk mengalami komplikasi kehamilam bahkan kematian pada maternal, dapat terjadi kehamilan prematur, BBLR, dan kematian perinatal (Hayati, 2010). Sehingga peningkatan pengetahuan bagi remaja putri mengenai anemia dan asupan zat gizi pada makanan itu penting sebagai upaya pencegahan terhadap kejadian anemia (Dharmadi, dkk, 2012).

Prevalensi anemia pada remaja putri lebih besar daripada remaja putra yang artinya remaja putri lebih rentan untuk terkena anemia. Anemia lebih sering terjadi pada remaja putri karena setiap bulan remaja putri menstruasi. Remaja putri yang mengeluarkan darah menstruasi sangat banyak selama lebih dari lima hari dikhawatirkan akan kehilangan zat besi, sehingga tubuh remaja putri memerlukan zat besi pengganti lebih banyak daripada hanya mengeluarkan darah menstruasi selama tiga hari dan sedikit. Ditambah lagi remaja putri umumnya lebih memperhatikan penampilan fisiknya sehingga usaha diet atau mengurangi porsi makan dilakukan untuk selalu menjaga tubuhnya tetap langsing. 
Ketidakseimbangan zat gizi atau makanan yang dikonsumsi karena diet dengan kebutuhan zat gizi tubuh, secara tidak langsung dapat menyebabkan tubuh kekurangan zat besi yang penting bagi tubuh (Arisman, 2007).

Menurut Depkes (2008), dilaporkan bahwa remaja putri di Indonesia banyak yang mengalami anemia dikarenakan kurang mengkonsumsi makanan dari sumber protein hewani yang kaya zat besi dan mudah diserap tubuh (hemeiron). Apabila jumlah zat besi di dalam tubuh berkurang dapat menimbulkan hambatan dalam pertumbuhannya baik sel tubuh maupun sel otak. Apabilah dalam darah kadar $\mathrm{Hb}$ berkurang dapat menimbulkan gejala tubuh merasa cepat capek, lemah, letih, lelah dan lesu. Adapun akibat dari gejala anemia tersebut adalah prestasi belajar remaja dapat menurun, malas berolahraga dan produktivitas kerja menurun, serta imunitas tubuh menurun sehingga tubuh mudah terinfeksi. Bagi remaja yang sudah bekerja maka produktivitas kerja dapat menurun apabila mengalami anemia, sedangkan remaja yang masih sekolah maka kemampuan akademis dapat menurun.

Survei pendahuluan pada Mahasiswa prodi DIII Kebidaan Blora dengan wawancara pada 8 mahasiswi, 5 mahasiswi mengalami lemah, letih dan kurang konsentrasi belajar pada saat menstruasi serta pada pemeriksaan fisik terlihat konjungtiva yang pucat. Hal ini di sebabkan karena pola makan yang tidak baik dan asupan zat besi yang kurang. Berdasarkan permasalahan tersebut maka menjadi pertimbangan penulis untuk melakukan pengabdian masyarakat tentang Pemeriksaan kadar Hb mahasiswi Prodi DIII Kebidanan Blora Poltekkes Kemenkes Semarang dalam upaya deteksi dini kejadian anemia sebagai persiapan untuk masa reproduksi. Selain itu diperlukan penyuluhan untuk meningkatkan kesadaran dirinya dalam pencegahan dan mengatasi kejadian anemia.

\section{TINJAUAN PUSTAKA}

Anemia merupakan kondisi dimana kadar hemoglobin $(\mathrm{Hb})$ dalam darah tidak sesuai dengan batas yang direkomendasikan yaitu $\geq 12$ gr/dl (WHO, 2007). Di Indonesia anemia zat besi merupakan masalah terkait dengan asupan gizi dalam tubuh yang menempati posisi paling tinggi. Akibat kekurangan zat gizi dalam tubuh dapat mempengaruhi pembentukan hemoglobin yaitu besi, protein, vitamin $\mathrm{C}$, Piridoksin, vitamin E (Almatsier, 2009). Adapun tanda dan gejala anemia dapat dilihat seperti tubuh merasa mudah letih dan lemah, sering mengantuk, merasa malas, sering pusing atau sakit kepala, kulit dan wajah kelihatan pucat, kurang nafsu makan, merasakan mual dan muntah (Varney, 2010).

Pada remaja putri kadar $\mathrm{Hb}$ normalnya adalah $\geq 12 \mathrm{~g} / \mathrm{dl}$. Anemia pada remaja putri adalah jika pada pemeriksaan kadar $\mathrm{Hb}<12$ gr/dl (Proverawati, 2011). Untuk menegakkan diagnosa anemia pada remaja putri dapat dilakukan dengan melihat tanda dan gejala anemia serta hasil pemeriksaan hemoglobin. Menurut Departemen 
Kesehatan RI (2013) diagnosis anemia, yaitu ringan sekali : Hb 11 g/dl sampai batas normal, ringan : $\mathrm{Hb} 8 \mathrm{~g} / \mathrm{dl}$ sampai kurang dari $11 \mathrm{~g} / \mathrm{dl}$, sedang : $\mathrm{Hb} 5 \mathrm{~g} / \mathrm{dl}$ sampai kurang dari $8 \mathrm{~g} / \mathrm{dl}$, dan berat : $\mathrm{Hb}$ kurang dari $5 \mathrm{~g} / \mathrm{dl}$. Menurut Prawirohardjo (2009), macam-macam anemia diantaranya adalah anemia defisiensi besi, anemia megaloblastik, anemia hemolitik, anemia hipoplastik dan aplastik (Myles, 2009).

Anemia sangat erat hubungannya dengan masalah kesehatan reproduksi seorang perempuan. Jika perempuan tersebut sudah mengalami anemia maka akan mempunyai peluang untu melahirkan bayi BBLR (berat badan bayi lahir rendah yaitu $<2500$ gr. Lebih ekstrimnya anemia dapat mengakibatkan kematian maternal atau neonatal pada saat proses persalinan (BKKBN, 2007). Umumnya pertumbuhan anak remaja sangat cepat. Apabila remaja mengkonsumsi zat gizi yang baik dan sesuai dengan kebutuhan untuk pertumbuhan dan aktivitasnya, maka dapat terjadi kekurangan zat gizi yang penting untuk tubuhnya sehingga pertumbuhannya dapat terganggu. Pada umumnya remaja putri akan mengalami menarche (pertama kali menstruasi), dimana pada saat menstruasi akan ada zat besi atau Fe yang akan dibuang. Sehingga apabila tubuh kita tidak cukup mengkonsumsi Fe, maka akan terjadi defisiensi Fe (zat besi) yang artinya terjadi anemia (Notoatmodjo, 2007).

Anemia pada remaja mempunyai dampak besar terhadap tubuh yaitu pertumbuhan akan terganggu dan tubuh mudah mengalami infeksi sehingga berkurangnya kebugaran tubuh, berkurangnya motivasi belajar sehingga menurunnya prestasi, mempunyai resiko tinggi apabila nantinya hamil (Subeno, 2008). Menurut Almatzier (2009), pencegahan dan penanganan anemia adalah dengan meningkatkan konsumsi makanan yang bergizi terutama makanan dengan sumber zat besi dari baik dari protein hewani, kacang - kacangan, sayuran hijau, dapat juga dengan minum tablet tambah darah (TTD), perlunya istirahat dan tidur yang cukup terutama setelah melakukan aktivitas yang cukup melelahkan. Sedangkan faktor yang mempengaruhi anemia pada remaja putri adalah pendapatan orang tua, pendidikan orang tua, lama menstruasi, makanan, konsumsi zat besi.

\section{METODE}

Pengabdian masyarakat dilakukan pada seluruh mahasiswa Prodi DIII Kebidanan Blora yaitu sejulah 132 mahasiswa. Kegiatan pertama dengan melakukan penyuluhan pada seluruh mahasiswa prodi DIII Kebidanan Blora mengenai anemia. Setelah kegiatan selesai dilanjutkan dengan pemeriksaan berupa anamnesa dan pemeriksaan fisik tanda dan gejala anemia. Kemudian dilakukan pemeriksaan laboratorium $\mathrm{Hb}$ bagi mahasiswa yang kira-kira menunjukkan tanda dan gejala anemia. 


\section{HASIL}

Kegiatan pengabdian masyarakat diikuti oleh seluruh mahasiswa baik tingkat I, II atau III dengan jumlah 132 mahasiswa. Kegiatan dilakukan dalam 3 gelombang. Adapun materi penyuluhan berupa pengertian anemia, penyebab anemia, patofisiologi anemia, tanda dan gejala anemia, dampak anemia, pencegahan anemia dan penanganan anemia. Setelah acara penyuluhan selesai kemudian dilakukan anamnesa dan pemeriksaan fisik tanda gejala anemia.

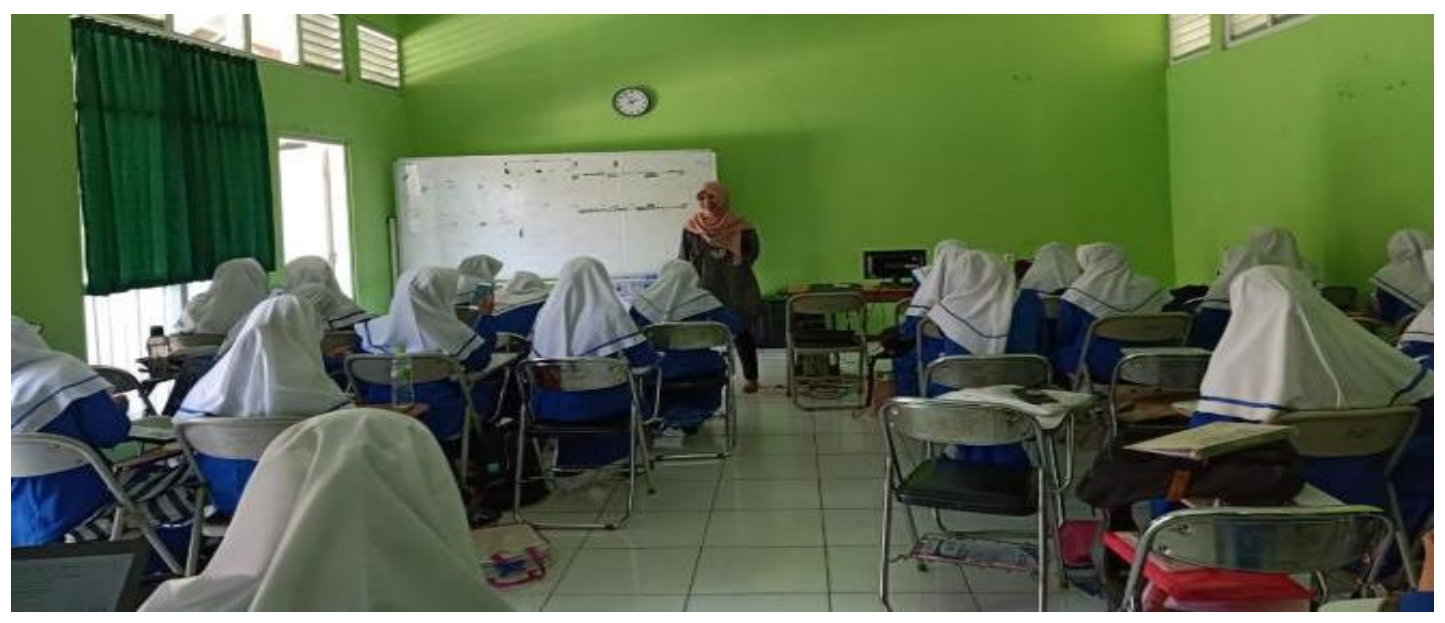

Gambar 1. Penyuluhan tentang Anemia

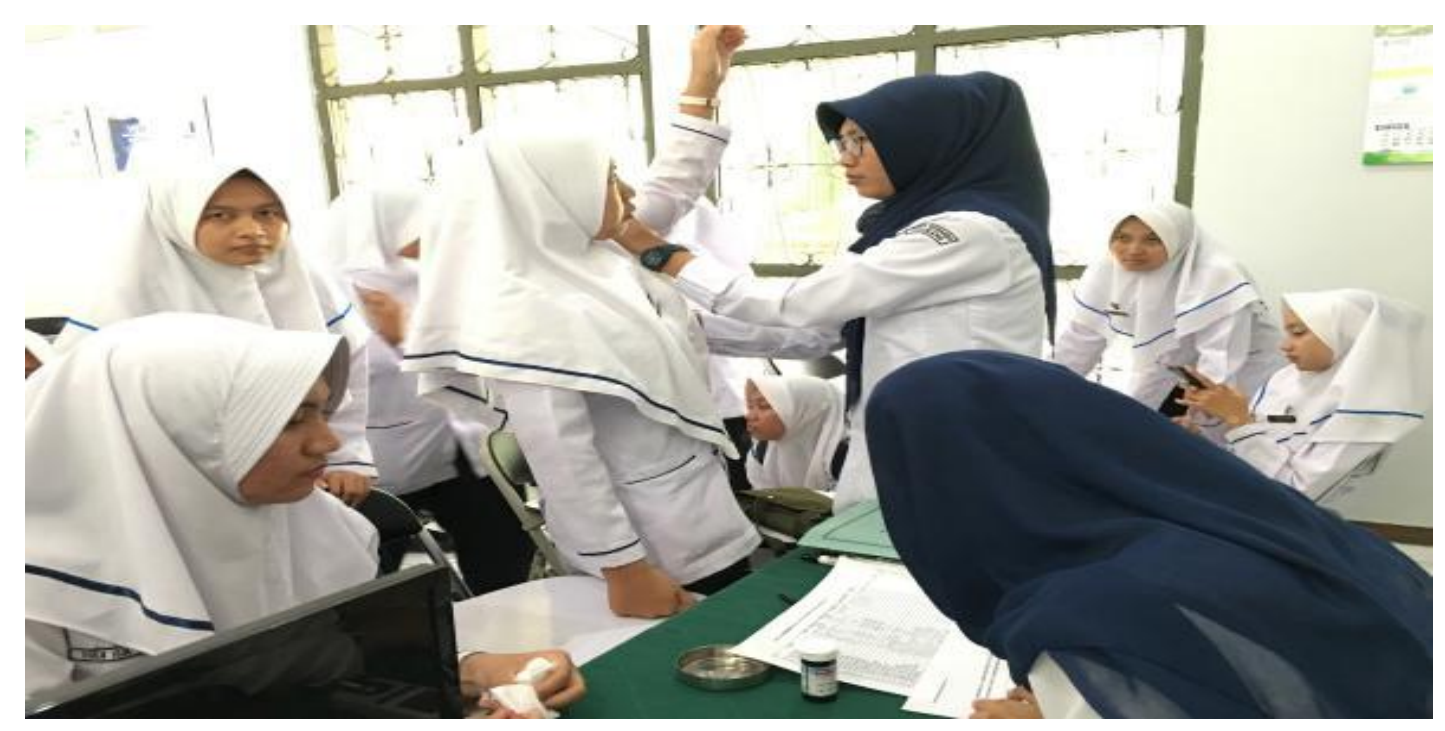

Gambar 2. Melakukan Anamnesa dan Pemeriksaan Fisik

Kemudian tahap terakhir dilakukan pemeriksaan laboratorium $\mathrm{Hb}$ bagi yang menunjukkan tanda dan gejala anemia. Dari 132 mahasiswa, hanya 30 mahasiswa yang dilakukan pemeriksaan laboratorium $\mathrm{Hb}$ dengan rincian sebagai berikut: 
Tabel 1. Gambaran Karakteristik Responden dari Hasil Pemeriksaan Hb, Umur, Menarche dan Lama Haid

\begin{tabular}{lccccc}
\hline & Mean & Median & SD & Min & Max \\
\hline Kadar $\mathrm{Hb}(\mathrm{gr} / \mathrm{dl})$ & 11,87 & 12,05 & 0,68 & 7,6 & 16 \\
Umur & 18,53 & 18,5 & 1,99 & 17 & 20 \\
Menarche & 12,53 & 12 & 1,04 & 11 & 15 \\
Lama Haid & 6,9 & 7 & 0,99 & 5 & 10 \\
\hline
\end{tabular}

Hasil analisis dari 30 mahasiswa yang diperiksa kadar $\mathrm{Hb}$ maka didapatkan untuk mean kadar $\mathrm{Hb} 11,87 \mathrm{gr} / \mathrm{dl}$ dengan range 7,6 - 16 gr/dl. Menurut umur maka mahasiswa kebidanan berkisar antara umur 17 - 20 tahun. Sedangkan untuk umur menarche berkisar antara umur 11 - 15 tahun. Untuk lama haid rata-rata 6,9 hari dengan SD 0,99 dan range 5 - 10 hari.

Agar mudah diinterpretasikan, maka dari hasil analisis data pada tabel 1 dikategorikan sebagai berikut:

Tabel 2. Gambaran Hasil Pemeriksaan Laboratorium

\begin{tabular}{lcc}
\hline Hasil pemeriksaan $\mathbf{H b}$ & Presentase & f \\
\hline Tidak Anemia $(>12 \mathrm{gr} / \mathrm{dl})$ & $53,30 \%$ & 16 \\
Anemia $(<12 \mathrm{gr} / \mathrm{dl})$ & $46,70 \%$ & 14 \\
\hline
\end{tabular}

Hasil pemeriksaan laboratorium $\mathrm{Hb}$ menunjukkan bahwa dari 30 responden, presentase antara yang anemia dengan tidak anemia hampir sama.

Tabel 3. Gambaran Karakteristik Responden Berdasarkan Umur

\begin{tabular}{ccc}
\hline Umur & Presentase & f \\
\hline 17 & $3,30 \%$ & 1 \\
18 & $46,70 \%$ & 14 \\
19 & $43,30 \%$ & 13 \\
20 & $6,70 \%$ & 2 \\
\hline
\end{tabular}

Hasil anamnesa dari 30 responden didapatkan bahwa responden terbanyak berusia 18 tahun adalah 46,7\% (14 mahasiswa).

Tabel 4. Gambaran Karakteristik Responden Berdasarkan Lama Haid

\begin{tabular}{ccc}
\hline Lama Haid & Presentase & f \\
\hline$\leq 5$ hari & $10 \%$ & 3 \\
6 - 7 hari & $73,30 \%$ & 22 \\
$>7$ hari & $16,70 \%$ & 5 \\
\hline
\end{tabular}


Hasil anamnesa dari 30 responden didapatkan bahwa lama haid mahasiswa terbanyak adalah 6-7 hari atau seminggu yaitu 73,3\% (22 mahasiswa).

Tabel 5. Gambaran Karakteristik Responden Menurut Pekerjaan Ayah

\begin{tabular}{lcc}
\hline Pekerjaan Ayah & Presentase & f \\
\hline PNS & $13,30 \%$ & 4 \\
Karyawan Swasta & $10 \%$ & 3 \\
Wiraswasta & $30 \%$ & 9 \\
Buruh/Petani/Nelayan & $36,70 \%$ & 11 \\
Tidak Bekerja/ Pensiun & $10 \%$ & 3 \\
\hline
\end{tabular}

Hasil anamnesa dari 30 responden menunjukkan bahwa sebagian besar pekerjaan ayah responden adalah buruh/petani/nelayan yaitu $36,7 \%$ (11 mahasiswa).

Tabel 6. Gambaran Karakteristik Responden Berdasarkan Pekerjaan Ibu

\begin{tabular}{lcc}
\hline Pekerjaan Ibu & Presentase & f \\
\hline PNS & $23,40 \%$ & 7 \\
Karyawan Swasta & $3,30 \%$ & 1 \\
Wiraswasta & $16,70 \%$ & 5 \\
Buruh/Petani/Nelayan & $3,30 \%$ & 1 \\
Tidak Bekerja/ IRT & $53,30 \%$ & 16 \\
\hline
\end{tabular}

Hasil anamnesa dari 30 responden didapatkan bahwa untuk pekerjaan ibu responden terbanyak adalah tidak bekerja/ IRT (Ibu Rumah Tangga) yaitu 53,3\% (16 mahasiswa).

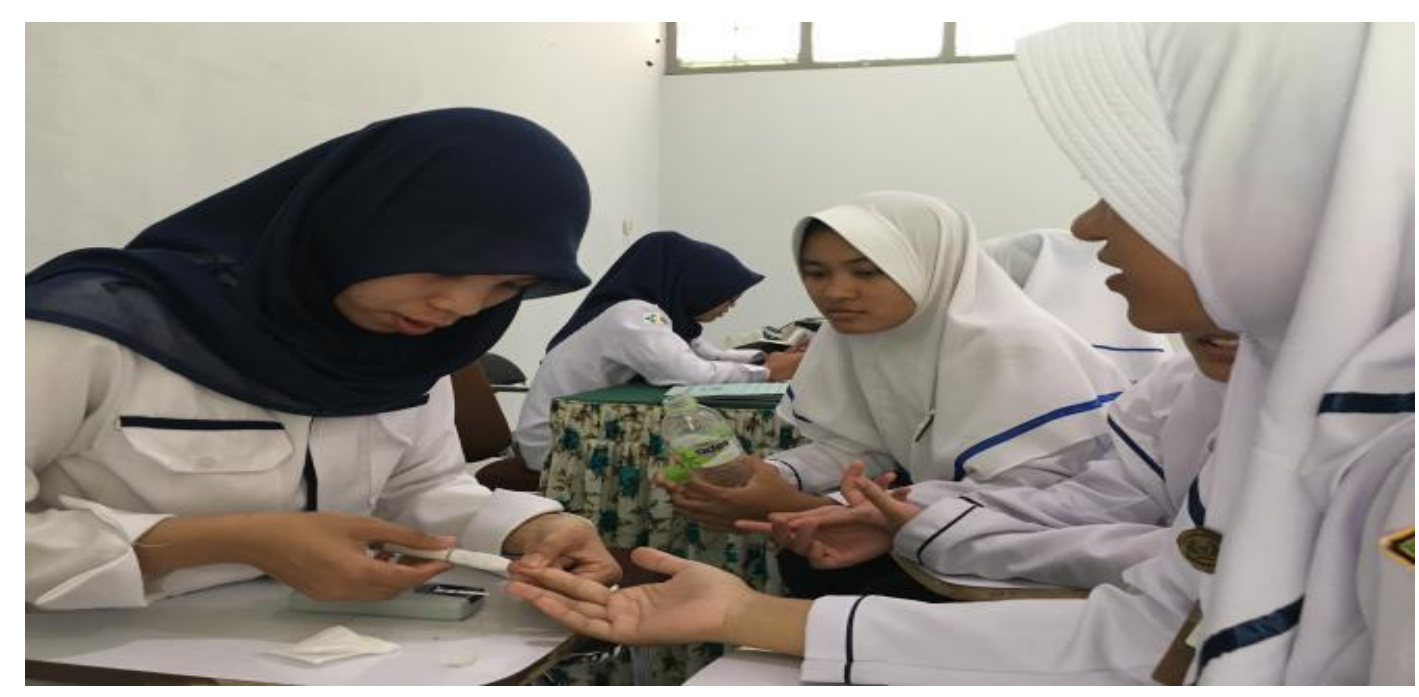

Gambar 2. Pemeriksaan Laboratorium $\mathrm{Hb}$ 


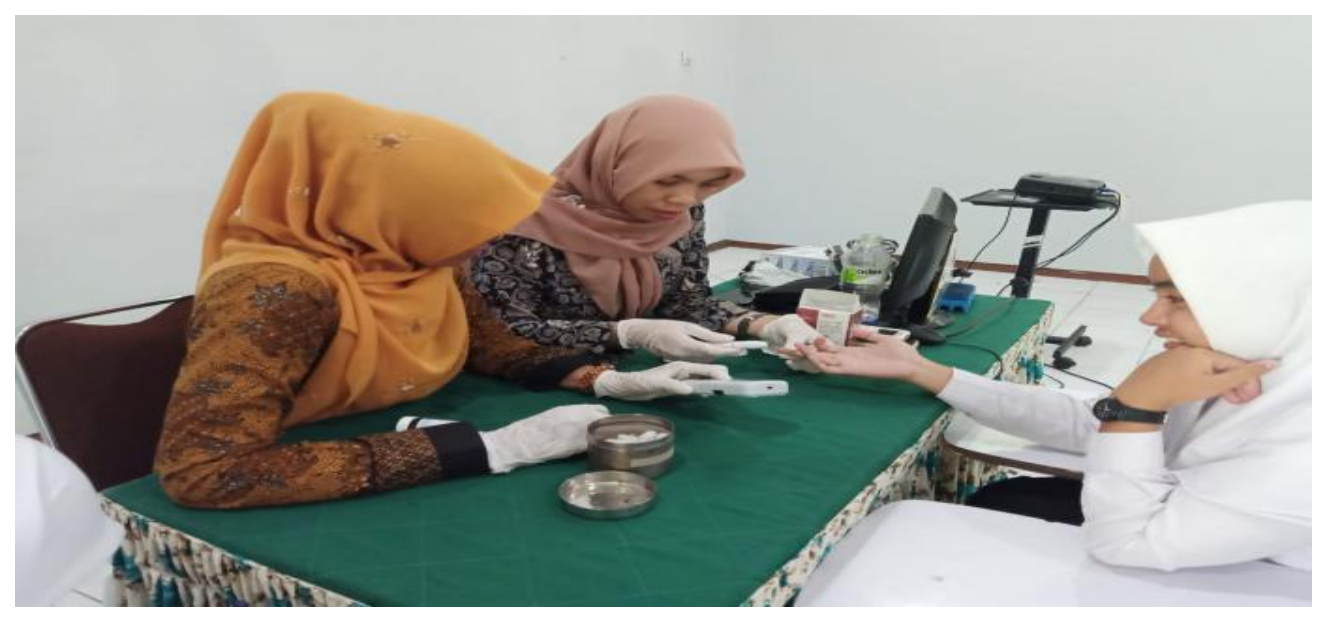

Gambar 3. Pemeriksaan Laboratorium $\mathrm{Hb}$

\section{PEMBAHASAN}

Kegiatan pengabdian masyarakat yang diawali dengan penyuluhan kepada seluruh mahasiswa kebidanan. Rangkaian kegiatan berjalan lancar dan dihadiri oleh seluruh mahasiswa kebidanan baik dari tingkat I, II dan III dengan 3 gelombang. Hasil penyuluhan tentang anemia didapatkan hasil bahwa mahasiswa sudah mengerti mengenai definisi anemia, penyebab anemia, tanda gejala anemia, pencegahan anemia dan penanganan anemia, dapat dilihat dengan mengajukan beberapa pertanyaan secara lisan diakhir penjelasan. Hal ini sesuai dengan pendapat Notoadmojo (2012) bahwa penyuluhan merupakan salah satu cara agar seseorang memperoleh pengetahuan. Pengetahuan merupakan hasil tahu dan terjadi apabila seseorang sudah melakukan penginderaan pada suatu objek. Pengetahuan merupakan unsur yang penting dalam seseorang melakukan tindakan atau keputusan. Disini mahasiswa dibekali pengetahuan tentang anemia sebagai upaya mencegah terjadinya anemia sehingga dapat dieliminasi dampak atau akibat dari anemia.

Dari hasil anamnesa dan pemeriksaan fisik maupun laboratorium didapatkan bahwa usia responden berkisar antara 17 - 20 tahun yang menandakan masih dalam usia remaja. Usia pertama kali haid (menarche) responden yaitu berkisar antara usia 11-15 tahun. Hal ini sesuai dengan pendapat Sarwono (2007) bahwa menarche umumnya berkisar dalam rentang usia 10 - 15 tahun. Sebanyak 46,7\% responden yang mengalami anemia, hal ini sesuai dengan data SKRT (2012) bahwa remaja putri mengalami anemia pada usia 10 - 18 tahun 57,1\% dan menurut Permaesih D. dan Herman S. (2005) bahwa prevalensi anemia remaja usia 10 - 19 tahun sebesar 25,5\%. Anemia sering menyerang remaja putri disebabkan karena keadaan stress, haid atau terlambat makan (WHO, 2010). 
Dari hasil anamnesa diperoleh data bahwa sebagian besar remaja putri mengalami lama haid sekitar 6-7 hari atau satu minggu. Hanya sebagian kecil yang haid sama atau kurang dari 5 hari. Durasi paling umum berlangsung 3 - 5 hari, namun durasi 2 sampai 7 hari dikatakan masih dalam batas normal (Judarwanto, 2008). Pada saat haid darah keluar bersamaan dengan zat besi keluar, sehingga apabila tidak cukup asupan zat besi akan mengakibatkan anemia (Wiknjosastro, 2007). Hal tersebut didukung oleh pendapat Arisman (2007) bahwa seorang remaja putri yang mengeluarkan darah menstruasi sangat banyak selama lebih dari lima hari kemungkinan zat besi dalam tubuh akan berkurang atau hilang, sehingga tubuh remaja putri memerlukan zat besi pengganti lebih banyak daripada hanya mengeluarkan darah menstruasi selama tiga hari dan sedikit. Beberapa zat gizi yang diperlukan untuk memproduksi sel darah merah (eritrosit) diantaranya zat besi (Fe), Vit Bc (asam folat), dan Vit B12 (cyanocobalamine). Bahan lainnya yang juga diperlukan antara lain protein, piridoksin (Vit B6), asam askorbat (ascorbic acid, bahan dasar Vit C), Vit E, dan tembaga (Proverawati \& Asfuah, 2009).

Di zaman sekarang pada usia remaja putri sering memperhatikan postur tubuhnya, sehingga banyak cara yang dilakukan yaitu seperti diet atau membatasi porsi makanannya. Bahkan banyak remaja putri yang asal berdiet yaitu melakukan diet tanpa pengawasan seorang ahli kesehatan dan gizi. Diet yang dilakukan terkadang sangat tidak sesuai dengan pedoman dalam ilmu gizi. Banyaknya pantang makanan yang dikonsumsi terkadang hanya berdasarkan analisa diri sendiri atau karena mendengarkan informasi dari temannya yang kurang paham mengenai ilmu gizi dan kesehatan, sehingga nantinya dapat menimbulkan berbagai tanda dan gejala kemunkinan merupakan gejala akibat kurang gizi seperti anemia. Remaja putri terkadang sering melewatkan 2 kali waktu makannya dan lebih memilih mengemil snack. Padahal sebagian besar snack yang dikonsumsi hampa kalori dan juga sedikit sekali mengandung zat gizi, selain itu snack dapat mengganggu (menghilangkan) nafsu makan. Apalagi maraknya makanan cepat saji sekarang ini, membuat kaum remaja putri ingin mencoba dan akhirnya ketagihan untuk makan makanan cepat saji (jun food) yang sangat sedikit atau bahkan ada yang tidak ada sama sekali kandungan kalsium, besi, riboflavin, Asam folat dan vitamin A (Djaeni, 2010). Hal ini dapat mentimulasi pembuluh darah, mengurangi spasme dari otot dan ambang nyeri berkurang, sensasi rasa nyeri hilang (Simkinm, 2005).

Dari hasil anamnesa diketahui bahwa sebagian besar ayah maupun ibu responden bekerja, dimana hal ini behubungan dengan pendapatan orang tua. Pola makan yang dibeli sangat dipengaruhi oleh besarnya pendapatan keluarga. Apabila mendapatkan uang tambahan atau bonus, sebagian besar akan digunakan untuk membeli makanan. Faktor pendapatan keluarga akan sangat menentukan kualitas dan kuantitas makanan yang dibeli sehingga dapat dikatakan bahwa ada hubungan 
yang erat antara pendapatan keluarga dengan asupan zat gizi. Pendapatan keluarga yang rendah tentunya akan mempengaruhi jenis makanan yang dibeli sehingga berdampak juga pada kualitas makanan, jumlah dan variasi makanan yang dikonsumsi oleh kaum remaja (Supariasa, 2006).

Menurut Depkes (2008), pada remaja putri di Indonesia banyak yang mengalami anemia dikarenakan remaja putri defisiensi dalam konsumsi makanan yang mengandung protein hewani yang merupakan sumber zat besi (Fe) yang sangat mudah tubuh serap (hemeiron). Apabila jumlah zat besi di dalam tubuh berkurang dapat menimbulkan hambatan dalam pertumbuhannya baik sel tubuh maupun sel otak. Apabilah dalam darah kadar $\mathrm{Hb}$ berkurang dapat menimbulkan gejala tubuh merasa cepat capek, lemah, letih, lelah dan lesu. Adapun akibat dari gejala anemia tersebut adalah prestasi belajar remaja dapat menurun, malas berolahraga dan roduktivitas kerja menurun, serta imunitas tubuh menurut sehingga tubuh mudah terinfeksi. Pada remaja yang masih sekolah akan kemampuan akademis dapat menurun karena gangguan atau banberkurangnya daya konsentrasi (Caturiyantiningtiyas, 2016).

\section{KESIMPULAN DAN SARAN}

\subsection{Kesimpulan}

Pada kegiatan pengabdian masyarakat dengan sasaran mahasiswa kebidanan, telah dilakukan penyuluhan yang dihadiri oleh seluruh mahasiswa. Mahasiswa memahami tentang materi anemia setelah dilakukan evaluasi. Anamnesa dan pemeriksaan fisik serta pemeriksaan laboratorium telah dilakukan pada 30 mahasiswa kebidanan dengan hasil 53,3\% tidak anemia dan 46,7\% anemia. Baik penyuluhan, anamnesa atau pemeriksaan dilakukan sebagai upaya pencegahan dan penanganan anemia.

\subsection{Saran}

Diharapkan dari hasil kegiatan pengabdian masyarakat yang dilakukan dapat sebagai pedoman untuk mencari solusi dari permasalahan yang ada. Pemberian motivasi kepada mahasiswa dengan menyadarkan mahasiswa untuk memperhatikan kesehatannya dengan cara mengkonsumsi makanan bergizi dan mengandung zat besi atau meminum tablet tambah darah adalah hal yang dapat dilakukan.

\section{UCAPAN TERIMA KASIH}

Ucapan terimakasih kepada pihak kampus, Prodi DIII Kebidanan Blora Poltekkes Kemenkes Semarang yang telah memfasilitasi sarana dan prasarana untuk kegiatan pengabdian masyarakat dan juga teman dosen yang ikut membantu dalam kegiatan pengabdian masyarakat kepada mahasiswa kebidanan. 


\section{DAFTAR RUJUKAN}

Almatsier, Sunita. (2009). Prinsip Dasar Ilmu Gizi. Jakarta : Gramedia.

Arisman, M.B. (2007). Buku Ajar Ilmu Gizi dalam Daur Kehidupan. Penerbit Buku Kedokteran. EGC: Jakarta.

Bakta, I. M. (2009). Anemia Defisiensi Besi. Jakarta : Pusat Penerbitan Departemen Ilmu Penyakit Dalam Fakultas Kedokteran Universitas Indonesia.

BKKBN. (2007). Penanggulangan Masalah Kesehatan Reproduksi. Jakarta.

Burner. (2012). Faktor-Faktor yang Berhubungan Dengan Kejadian Anemia Pada Remaja Putri. Jurnal di akses tanggal 09 September 2019.

Caturiyantiningtiyas, T. (2016). Hubungan Antara Pengetahuan, Sikap Dan Perilaku Dengan Kejadian Anemia Remaja Putri Kelas X Dan Xi Sma Negeri 1 Polokarto [Ilmu Kesehatan Masyarakat, Fakultas Ilmu Kesehatan, Universitas Muhammadiyah Surakarta]. http://eprints.ums.ac.id/39689/1/naskah publikasi.pdf

Departemen Kesehatan RI. (2008). Program Penanggulangan Anemia Gizi pada Wanita Usia Subur (WUS). Jakarta : Direktorat Jenderal Bina Kesehatan Masyarakat

Dharmadi, M. dkk. (2012). Penyuluhan anemia Defisiensi Besi (ADB) pada remaja puteri di Sekolah Menengah Atas Negeri 1 Bangli. http://www.communityhealthy.com/penyuluhan-anemia-defisiensibesipada-re maja-puteri-di-smaNegeri1-bangli.htm.

Djaeni, Sediaoetama Achmad (2010). Ilmu Gizi. Jakarta.

Hayati, R.M., (2010). Pengetahuan dan Sikap Remaja Puteri tentang Anemia Defisiensi Besi dan Dampaknya terhadap Kesehatan Reproduksi. Medan. Skripsi USU

Judarwanto, W. (2008). Perilaku Makan Anak Sekolah. Diakses tanggal 31 Agustus 2019. http://www.litbang.depkes.go.id/aktual/anak/ makanan140206.html 
Kementrian Kesehatan RI. (2013). Riset Kesehatan Dasar, Jakarta : Badan Penelitian dan Pengembangan Kesehatan

Merryana dan Bambang. (2012). Pengantar Gizi Masyarakat. Jakarta: Kencana Myles. (2009). Buku Ajar Bidan. Jakarta: EGC.

Notoatmodjo, S. (2007). Promosi Kesehatan dan Ilmu Perilaku. Jakarta : Rineka Cipta.

Notoadmojo, S. (2012). Promosi Kesehatan dan Perilaku Kesehatan. Jakarta: PT Rineka Cipta

Permaesih, D. \& Herman, S. (2005). Faktor-faktor Yang Mempengaruhi Anemia Pada Remaja. Buletin Penelitian Kesehatan Volume 33 Nomor 4.

Prawirohardjo S. (2009). Buku Acuan Pelayanan Kesehatan Maternal dan Neonatal. Jakarta : PT Bina Pustaka Sarwono Prawirohardjo

Proverawati, A., \& Wati, E. K. (2011). Ilmu Gizi untuk Keperawatan dan Gizi Kesehatan. Yogyakarta: Nuha Medika.

Proverawati, Asfuah S., (2009). Buku Ajar Gizi untuk Kebidanan. Yogyakarta: Nuha Medika

Sarwono. (2007). Psikologi Remaja. Jakarta : Raja Grafido Persada

Simkin, Penny \& Ancheta, R. (2005). Buku saku persalinan. Jakarta. EGC.

Subeno. (2008). Anemia Defisiensi Besi pada Anak Sekolah. Cermin Dunia Kedokteran. www.kalbe.com. Diakses Tanggal 12 September 2019.

Supariasa. (2001). Penilaian Status Gizi. Buku Kedokteran EGC.Jakarta.

Varney, Helen. (2010). Buku Ajar Asuhan Kebidanan Edisi 4. Jakarta. EGC

Wiknjosastro, Hanifa. (2007). Ilmu Kebidanan. Jakarta : YBP-SP.

World Health Organization., (2007). Iron Deficiency Anemia Assasment, Prevention and Control Aguide for Program Manager. 
84 Jurnal Empathy, Volume 1, No 1, Juni 2020, hlm 1-95

World Health Organization. (2010). Haemoglobin Concentrations For The Diagnosis Of Anemia And Assesment Of Severity. www.who.int/vmnis /indicators/haemoglobin.pdf. Diakses pada tanggal 04 September 2019.

Yusuf, Syamsu. (2011). Psikologi Perkembangan Anak dan Remaja. Bandung : PT. Remaja Rosdakarya. 